\title{
渡邊祐実 学位論文審査要旨
}

$\begin{array}{cccc}\text { 主查 清 } & \text { 水 } \text { 英 治 } \\ \text { 副主查 原 } \text { 田 省 } \\ \text { 同 } \\ \text { 汐 } \text { 田 剛 史 }\end{array}$

\section{主論文}

CD437 induces apoptosis in ovarian adenocarcinoma cells via ER stress signaling （CD437は小胞体ストレスシグナルを介して卵巣腺癌細胞のアポトーシスを誘導する） （著者 : 渡邊祐実、土谷博之、坂部友彦、松岡さおり、明地雄司、藤本由佳、山根恵太郎、 池田礼美奈、西尾れん、寺林慶、石井恭子、権田一絵、松見吉朗、An Afida Ashla、 岡本秀治、田窪千子、富田暁子、星川淑子、栗政明弘、板持広明、原田省、 寺川直樹、汐田剛史)

平成20年 Biochemical and Biophysical Research Communications 366巻 840頁〜 847頁 


\section{学 位 論 文 要 旨}

\section{CD437 induces apoptosis in ovarian adenocarcinoma cells via ER stress signaling （CD437は小胞体ストレスシグナルを介して卵巣腺癌細胞のアポトーシスを誘導する）}

卵巣癌は化学療法が奏効する腫瘍であり、現在、パクリタキセルとカルボプラチン併用 療法の導入により、完全寛解率は改善されている。しかしながら、長期生存率は依然とし て不良であり、抗腫瘍効果の良好な新たな薬剤の開発が待たれている。

合成レチノイドCD437は、多様な癌細胞株に対して強力な抗腫瘍作用を発揮し、卵巣癌も そのひとつである。CD437はレチノイン酸受容体 (RAR) $\gamma$ 選択的なアゴニストとして作用し、 RAR依存性経路を活性化することが知られている。しかしながら、近年の研究から、CD437 による抗腫瘍作用にはRARを介さない経路の存在が示唆されている。本研究では、小胞体ス トレスに焦点を当て、卵巣癌由来細胞株SKOV3を用い、CD437の抗腫瘍作用機序の検討を行 った。その結果、CD437は、卵巣腺癌細胞株SKOV3において、小胞体（ER）ストレストラン

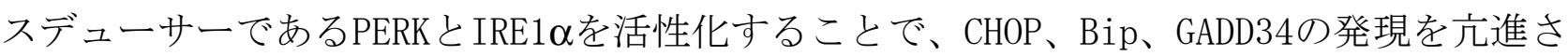
せ小胞体ストレスを引き起こすことを示した。さらに、siRNAを用いてCHOPの発現をノック ダウンしたところ、SKOV3細胞に対するCD437の増殖抑制作用は有意に減弱した。以上より、 CD437の卵巣癌細胞株におけるアポトーシス誘導メカニズムの一つとして、ERストレスの重 要性が示唆された。

\section{方 法}

卵巣癌由来細胞株SKOV3細胞を使用し、CD437を0.5-2 $\mu$ Mの濃度で、24-48時間処理した。 薬剂処理後の細胞内mRNA発現量はreal-time reverse transcriptase-polymerase chain reaction (RT-PCR) 法にて、蛋白質発現はウエスタンブロット法により検討した。アポトー シスはHoechst33258染色および活性型Caspase-3をウエスタンブロット法により評価した。 またXBP-1 mRNAのスプライシングは、RT-PCR後8\%ポリアクリルアミドゲル電気泳動にて解 析を行った。

\section{結 果}

CD437はSK0V3に対してアポトーシスを惹起し、さらに小胞体ストレスによって発現誘導 される遺伝子（CHOP、GADD34、BiP/GRP78）のmRNA量を有意に増加させた。このときCD437 
は、小胞体ストレストランスデューサーであるPERK、IRE-1 $\alpha$ の活性化と、さらにその下流 分子の活性化（eIF2 $\alpha$ のリン酸化、ATF4蛋白質発現、XBP-1 mRNAスプライシング）を誘導 した。しかし、もう一つの小胞体ストレストランスデューサーであるATF6の活性化は観察 されなかった。さらにCHOPに対するsiRNAを細胞に導入したところ、CD437に対する感受性 の低下が認められた。

\section{考 察}

これまでの報告からCD437は、RAR以外の経路からの遺伝子発現を介してアポトーシスを 誘導することが示唆されている。今回の研究の結果から、卵巣癌細胞株におけるCD437の新 たな作用機構として、小胞体ストレスの立進を介する経路が明らかとなった。一般に、小 胞体ストレスはPERK、IRE1、ATF6の3つのトランスデューサーを介してシグナル伝達される ことが知られている。これらによって最終的に活性化される転写因子ATF4、XBP1、p60ATF6 は核内に移行してamino acid regulatory element (AARE)、ER stress response element (ERSE)に作用し、CHOPの発現を誘導する。本研究において、siRNAを用いてCHOPをノックダ ウンすると、SKOV3におけるCD437の増殖抑制作用が阻害された。このことから、SKOV3にお いても、CHOPがCD437誘導アポトーシスに重要な役割を果たしていることが示された。本研 究では、SKOV3においてCD437がPERKとIRE1の経路を活性化することが明らかとなったが、 ATF6の活性化は認められなかった。またこれと同様に、CD437で処理した他の卵巣癌細胞株 においても、CHOPの発現増強が認められない細胞株もあった。これらの結果より、CD437 は卵巣腺癌細胞株において、明らかに小胞体ストレスを引き起こすが、その誘導経路は細 胞株間で異なっている可能性があり、今後さらなる研究が必要である。

\section{結 論}

合成レチノイド CD437の卵巣癌細胞株におけるアポトーシス誘導メカニズムの一つとし て、小胞体ストレスの重要性が示唆された。 